1975 Membership Dues. At the last annual meeting of the Association at Boston the members voted an increase of dues for non-student members to $\$ 30$. and for student members to $\$ 12.50$ Institutional Membership is now $\$ 40$. Most of this increase will cover rising printing casts for the Journal. Members will receive their bill for the coming year directly from Cambridge University Press; as in the past the subscription and membership dues are combined and should be paid directly to the Press, which then remits the Association's portion to this office.

Suggestions for Nominations. Members are urged to send suggestions for nominations to the Chairman of the Nominating Committee, Middle East Studies Association, New York University, Hagop Kevorkian Center for Near Eastern Studies, 50 Washington Square South, New York, N.Y. 10003.

Suggestions for Visiting Scholars. Members are also urged to send suggestions for the Visiting Scholars Program for 1975-76 to the MESA Secretariat. As much biographical information as possible, including addresses, should be included with the suggestions.

The Image of the Middle East in Secondary School Textbooks, a report by William J. Griswold of Colorado state University in collaboration with the other members of MESA's Image Committee, has just been published, The Image Committee was set up by MESA in 1971 to investigate the treatment of Middle East topics in secondary school textbooks. Working in cooperation with school districts in the US and Canada, Committee members reviewed more than 60 world history and social studies texts. In its final report, the committee maintains that "while some books were well researched and written, the majority contained factual errors, perpetuated stereotypes in political and social description, over-simplified complicated issues, listed outcomes while ignoring causes and provided moral judgements on the actions of nations in the guise of factual history".

The complete Image Committee Report includes a summary of the Committee findings, an annotated bibliography of textbooks commonly used in the US and Canada, syllabi on "Islamic History" and the "Four Arab-Israeli Wars: 1948-1973", and suggestions for classroom activities. Copies are available from the MESA Secretariat, New York University, Hagop Kevorkian Center for Near Eastern Studies, 50 Washington Square South, New York, N.Y. 10003, free of charge for members and $\$ 1.00$ for non-members.

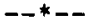

The State of the Art papers commissioned by the Research and Training Committee of MESA, chaired by professor Leonard Binder, will be published by Wiley press in 1975. The ten disciplinary chapters were prepared for a conference held at the Center for the Advanced Study of the Behavioral Sciences at Palo Alto in August 1973, attended by about fifty leading scholars on the area from North America, Europe and the Middle East. 


\section{Program Committee}

The 1975 annual meeting Program Committee of MESA invites proposals for three different types of participation in the ninth annual meeting at Louisville, Kentucky:

1) full panels of four papers, clearly related to each other and organized about a single topical theme

2) individuals paper proposals

3) workshops and roundtables with a list of participants and the central topic

Since there has been some criticism of the number of panels, the number of papers and the quality of papers at recent annual meetings, the Committee will take a careful look at all proposals in order to maintain high standards of quality in the Association. Each paper proposed (in the case of 1 and 2 above) or the general workshop and roundtable topic should be supported by a single page prospectus (no more than 250 words) in suitable form for inclusion in the Abstracts; the prospectus must contain sufficient information on sources and findings to provide the bases for evaluation by the program Committee.

The Middle East Studies Association of North America, Inc . (MESA) was organized in 1966 by a group of American and Canadian scholars on the Middle East to promote high standards of scholarship and instruction in the area, to facilitate communication among scholars through meetings and publications, and to foster cooperation among persons and organizations concerned with the scholarship study of the Middle East. The area included within the Middle East runs from Morocco to Pakistan and from Turkey to the Sudan. MESA is concerned with this area primarily since the rile of Islam and from the viewpoint of the social science and humanistic disciplines.

persons of scholarly attainment in Middle East studies are eligible to become members of MESA. Application for membership is made on an application form obtainable from the Executive Secretary, Middle East Studies Association, New York University, Hagop Kevorkian Center for Near Eastern Studies, Washington Square, New York 10003. Each application is acted upon individually. Membership is on a calendar year basis. 
The following New Members have joined MESA since last August. In some cases, former student or regular members have become Fellows.

Fe11 ows

Mohammed M. Aman, St.John's U. S.M.H. Ayatullahi, Pahlavi U. Robert B. Betts, Maryland U. Christopher Brunner, Columbia Dominique Chevallier, Sorbonne Nina G. Garsoian, Columbia Enshad Al-Imam, Univ. of Tunis Jean Leca, Univ. des Sciences

Sociales, France

\section{Regulars}

A. G. Aivazian, UCLA Lib.

Artin H. Arslanian, St. Olaf C. Tozun Bahcheli, King's C., Canada William R. Brown, Stockton State C. Conrad R. Case, Minnesota Allan R. Gal1, Colorado U. William Graham, Jr., Harvard Ruth Kark, N. Carolina U.

Roberg Gangwer, I1l. Wesleyan

\section{Associates}

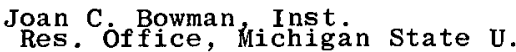

\section{Students}

Carl Belack, US Military Acad. Cynthia Chambers, AUB

Kathleen D. Crane, Boston C. James Lee Dugan, Woodstock C., NY Stephen Franke, N. Carolina State Max L. Gross, Georgetown Don Holsinger, Nor thwester

Vartan S. Kasparian, Utah

Daniel C. Kurtzer, Columbia
Safia K. Mohsen, SUNY Binghamton Sadok Masliyah, Oberlin C. Gordon N. Newby, Brandeis Dennis $R$. Papazian, Mich-Dearborn Ted. A. Rathbun, S. Carolina U. Eisig Silberschlag, Texas at Austin Norman A. Stillman, SUNY Binghamton Earle H. Waugh, Alberta U. John E. Woods, Chicago U.

Karin R. Lentzner, Georgetown Akbar Muhammad, Vanderbilt U. Veronica Pantelidis, Florida Res. Library

J. Meric Pessagno, W. Conn. C. K. Pobbi-Asamani, Arkansas U. Youssef $S$. Saad, Winston-Salem Madeleine Stuart, Arabian Oil Co. Lewis B. Ware, AIR Univ., Alabama Jesse C. Willmon, M. of Educ., Lebanon

Nick Pantelidis, Florida Allan Solomonow, CONAME, NYC

Linda M. Lamb, Columbia David Lawrence, Berkeley Niko Maksimyadis, Chicago Richard C. Martin, NYU

Ahmed Rhazaoui, NYU Jay L. Schulman, SUNY Binghamton Margaret E. Sears, Boston U. Dona sue Straley, Edinburgh, Scotland Margaret Wilder, Penn. 